\title{
Halep Geleneksel Evleri ve Özellikleri
}

\author{
Mahmud Zeyn El Abidin ${ }^{\star \star}$ \\ Suphi Saatçi $i^{\star \star \star}$
}

\section{Öz}

Tarihin en eski kentlerinden biri olan Halep, Türkiye’nin sınır komşusu Suriye'nin ticari, ekonomik ve endüstriyel başkenti niteliğindedir. Önemli ticaret yollarının buluştuğu kent, ülkenin kuzeyinde yer almaktadır. Konumu itibariyle kent, tarih boyunca doğu ile batı arasında bir ticaret merkezi olmuştur. Taş devrinden bu yana yerleşim yeri özelliğini koruyan Halep, Orta Tunç Çağı'nda bile nüfus topluluklarının merkezi olmuştur. Coğrafi konumu, dinî cazibesi, sosyal yapısı ve iklim şartları Halep'in ayakta kalmasını sağlayan başlıca etkenler olmuştur.

Halep kent dokusunun en ilgi çeken yanı geleneksel konut mimarisidir. Halep evlerinde eski doku incelendiğinde Anadolu'da benzer iklim ve sosyal yapıya sahip olduğu görülür. Organik sokak dokusu, sağır ve yüksek avlu duvarlarıyla çevrilidir. Ev mimarisini etkileyen ikilim, malzeme, gelenek, çevre, kültür ve sosyal hayat faktörleri, fiziki plana da yansımıştır. Halep geleneksel ev mimarisi Mezopotamya döneminden başlayarak İslam dönemine kadar varlığını sürdürmüştür.

Anahtar Kelimeler: Halep, geleneksel ev, Mezopotamya, birim, malzeme.

* $\quad$ Bu makale, Halep Kenti ve Geleneksel Evleri adlı doktora tezinden üretilmiştir.

** Doktora Öğrencisi, Fatih Sultan Mehmet Vakıf Üniversitesi Lisansüstü Eğitim Enstitüsü, İstanbul/Türkiye, mahmoud68@gmail.com, orcid.org/0000-0003-0270-7379

**** Prof. Dr., Fatih Sultan Mehmet Vakıf Üniversitesi Mimarlık ve Tasarım Fakültesi, İstanbul/ Türkiye, ssaatci@fsm.edu.tr, orcid.org/0000-0002-3775-4127 


\title{
The Characteristics of Traditional Houses of Aleppo
}

\begin{abstract}
Aleppo, as one of the oldest urban settlements, is the commercial, economic and industrial capital of Syria, the neighbor of Turkey on its southern border. The city, where important trade routes meet, is located in the north of the country. Aleppo has been a trade center between east and west throughout its history. Aleppo, which has preserved its character since the Stone Age, has been a center of attraction for communities even in the Middle Bronze Age. Geographical location, religious attractiveness, social structure, and climatic conditions were the main factors that enabled Aleppo to survive throughout the centuries.

The most interesting part of the urban fabric in Aleppo is its traditional residential architecture. When the urban residential fabric is examined in Aleppo, it is seen that it has similarities to the climatic and social structure in Anatolia. The streets with organic texture are surrounded by blind and high courtyard walls. The climate of the area, building materials, traditions, social and cultural environment have their physical effects on the residential architecture. The traditional residential architecture of Aleppo starting from the Mesopotamian period has lasted as well through the Islamic Period.
\end{abstract}

Keywords: Aleppo, traditional houses, Mesopotamia, building unit, building material. 


\section{Giriş}

Halep, Türkiye ile güneydoğudan 877 km uzunluğunda ortak kara sınırı olan Suriye'de yer alan bir kenttir. Türkiye sınırına yaklaşı $60 \mathrm{~km}$. mesafede bulunan Halep, Suriye'nin ikinci büyük kentidir. Eski Halep kentinin toplam alanı 355 hektardır ve günümüzde 5 milyona yakın nüfusu barındırmaktadır.

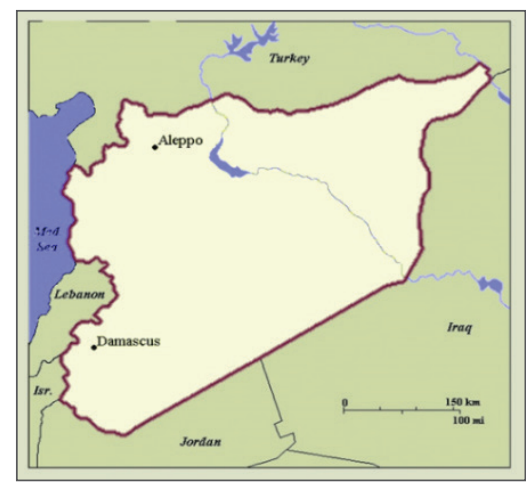

Şekil 1. Suriye haritas1

Eski Çağdan Orta Çağa uzanan Roma ve Arap İslam dönemine; Memluk, Selçuklu ve Osmanlı'ya kadar birçok uygarlığa ev sahipliği yapan Halep, İslam tarihinin en eski ve Orta Çağın en önemli ticaret kentlerinden biridir.

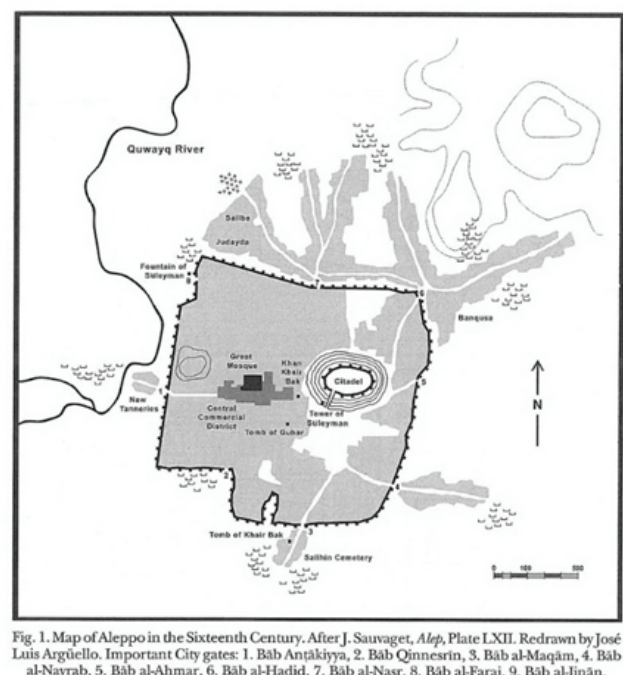

Şekil 2. 16. Yüzyılda Halep'in kentsel gelişimi

(Watenpaugh, Heghnar Zeitlian, The Image of An Ottoman City, Leiden, Boston, Brill, 2004) 
Halep Taş Devri'nden bu yana yerleşim özelliğini korumuş, Orta Tunç Çağı'nda nüfus topluluklarının merkezi olmuştur. Coğrafi konumu, dinî, sosyo-kültürel yapısı ve iklim şartları kentin ayakta kalmasını sağlamıştır'. İpekyolu arac1lığıyla Karadeniz limanlarından ve Uzakdoğu'dan çeşitli ticari ürünlerin uğrak yeri olan Halep, İskenderun, Lazkiye ve Beyrut’tan gelen kafileleri de ağırlamıştır. Kent bu bağlamda doğudan, güneyden ve kuzeyden gelen kafilelerin buluşma merkezi olmuştur. Böylece Akdeniz ve Mezopotamya coğrafyası, Acem ve Hindistan toplumları Halep'te buluşmuştur. Farklı medeniyetlerin ticaret amaciyla buluştuğu Halep kentinin halkı bu etkileşim sayesinde ticarette tecrübe kazanma firsatı bulmuşlardır².

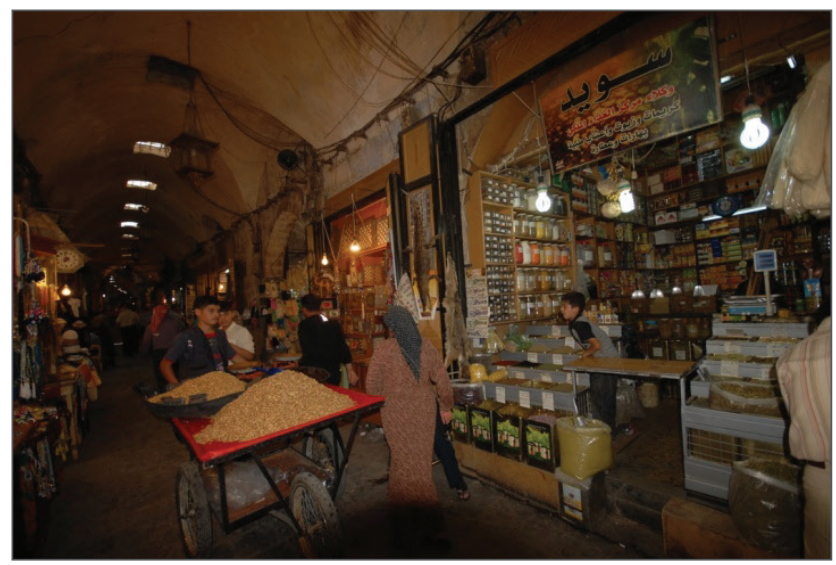

Şekil 3. Halep kapalı çarşısı (M. Zeyn El Abidin, 2009)

\section{Kent ve Mahalle Yapısı}

Osmanlı kentleri, genelde 5 ile 100 aile arası değişen sayıda mahallelerden oluşmaktadır. Halep'te bu sayı ortalama 30 veya 40 aileyi kapsamaktadır. Raymond'a göre ise bir mahallenin ortalama nüfusunu 1000-2000 kişi dolaylarında kabul etmek gerekmektedir. Bu sayı 200- 400 aileye denk düşmektedir. Mahalle sayısı da kentin büyüklüğüne göre değişmektedir³

Her mahallenin başında Halep'te "Kethüda" denilen kâhyalar bulunmaktadır. Mahallenin vergisi içerdiği hane sayısına göre hesaplanmaktadır. Örneğin Halep kenti için 1743 y1lında, 15.421 akçe vergi tahakkuku gerçekleşmiş ve bu rakam

1 Mahmut Faysal el-Rifai, Halep Beyne't-Tarih ve'l-Hendese, Camiat Halep, Ma'had el-Turas el-'İlmi el-'Arabi, 1417 H./1996 M., s. 38-39.

2 Hamide Abdurrahman, Muhafazat Halep, Şam, Menşurat Vüzaretü’s-Sakafa, 2006, s. 162.

3 Andre Raymound, el- 'Avasım el- 'Arabiyye ve 'Umraniha fi'l-Fetretü'l-Osmaniye, çev. Kasım Tuveyr, Şam, Darü’l-Mecd, 1986, s. 25-26. 
81 mahalleye eşit olarak bölünmüş ve her bir mahalledeki hane sayısına, kendi mahallesine düşen rakam tekrar bölünerek vergiler toplanmıştır. ${ }^{4}$

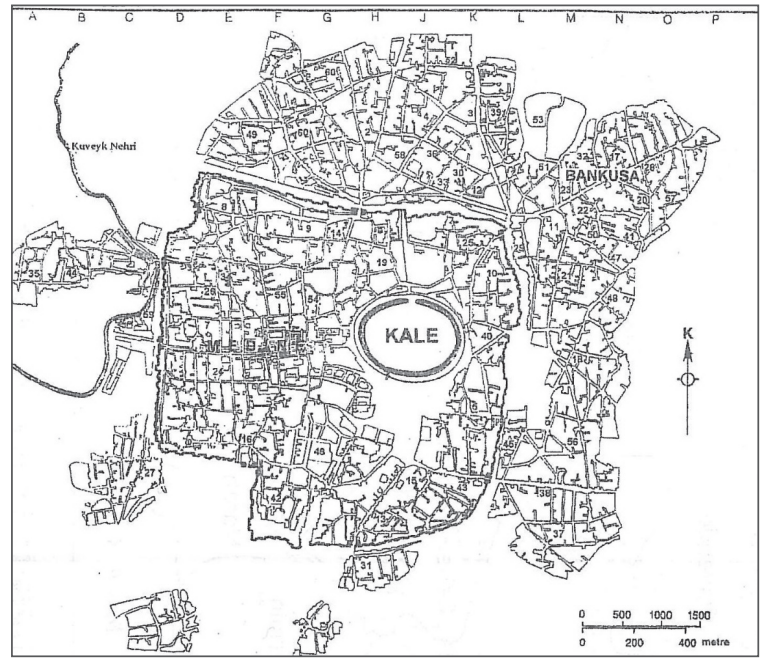

Şekil 4. Halep Şehrinin Yerleşim Planı (Mahalleler)

(Çakar, Enver, 17. Yüzyllda Halep Eyaleti ve Türkmenleri, Elazığ, Fırat Üniversitesi, 2006)

\section{Sokak ve Yapılar Arası İlişki}

Halep tarihî kent dokusundaki sokakların çoğu, geçmişten günümüze yapıs1 bozulmadan gelmeyi başaran dolambaçlı ve dar, doğal taşla döşenmiştir. Genişlikleri 3-3,5 m arasında olan sokaklar iki tarafi kaldırımlı ve ortasında suyun akmasını sağlayan "yağmur suyu akaçlaması" görevini üstlenmiş bir akıntı kanalından meydana gelmektedir. Sokakların enine kesitinde, ortada 6-10 cm kadar az bir derinliği olan su kanalı ve yayalar için ortalama 1,00-1,30 m genişliğinde kaldırımlar yer almaktadır. Halep'te dar sokaklar, iki taraftan evlerin yüksek ve sağır, beden veya avlu duvarları ile sınırlanmıştır. Dışarıdan sağır olarak görülen bu yüzeylerin arkasında yeşil, gölgeli, serin ve ferah avlular ile avlunun çevresinde yerleşmiş, evin kapalı mekânları yer almaktadır.

Geleneksel Halep konutları, dar sokakların birbirine bağladığı, bitişik nizamlı

4 Arap kentlerinin güvenlik sorununa ilişkin sundukları görüntü oldukça çelişkilidir. Bunu Sauvaget'in Halep tasvirinden yola çıkarak değerlendirmek kanımızca hayli yerinde olacaktır. $\mathrm{Bu}$ düzen hakkında Sauvaget: "Kentin görüntüsü, polis ve ulaşım yolları yönetmeliklerinin kalıcı damgasını taşımaktadır ve bu konuda Osmanlı idaresinin hakkını teslim etmek gerekir" şeklinde görüş belirtmiş̧ir (Raymond, a.g.e, 89-92) 
ve avlulu yapılar olarak tanımlanabilir. Halep geleneksel evlerinde yaşamın sokakla ilişkisi sınırlı tutulmuştur. Sosyal yapıda mahremiyet kavramının öne çıkmış olmasının bu noktada etkili olduğu söylenebilir. İlişkinin sokakla sınırlanmış olması ise konutlarda avlu eksenli bir yaşamın gelişmesini sağlamış ve sokaktan bakıldığında geleneksel bir Halep konutunun içinin nasıl olduğunu anlamayı imkânsız kılmıştır. Dışarıdan çok sade görünen birçok yapının, içeride oldukça zengin mimari elemanlarla süslenmiş olduğu görülür.
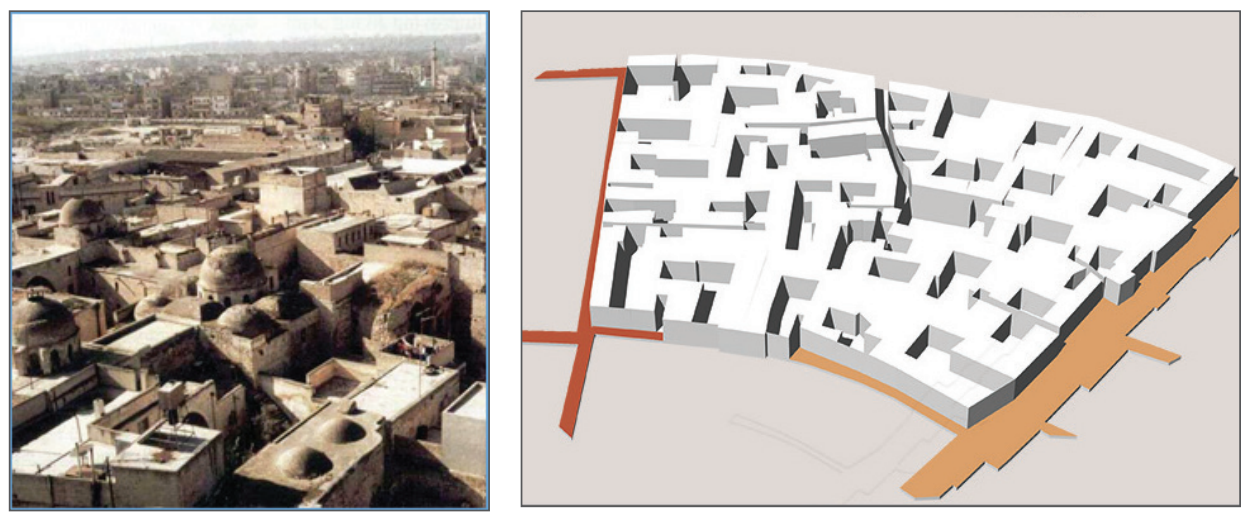

Şekil 5. Halep’teki evlerin bitişik nizamı (M. Zeyn El Abidin)

Tarihi kent sokaklarının bazılarında, birinci kat hizalarında yapıların birleştiği görülmektedir. Bunun sebebi ise kısıtlı alanın verimli kullanılmak istenmesidir. Bu kente özgü bir oluşum olan ve yörede "Sibat" denilen örtülü geçit, evlerin düşey olarak birbirleriyle bütünleşik yapısının sokaklar tarafından bölünen, bir bakıma kamusal bir bakıma özel olan alanlardır. Özellikle aynı ailenin farklı parselleri arasındaki geçişi sağlayan Sibat, sokakları da birbirine bağlar. Kentteki bütün Sibatlar ev sahibi ailenin ismiyle anılır. Girift kent dokusunda önemli röper noktaları oluşturan Sibatlar, aynı zamanda buluşma yerleridir. Sibatlar genelde kabaca işlenmiş moloz taştan sivri, basık ya da yuvarlak kemerli olarak yapılır. Taşların arasında kullanılan kırık testi parçaları gibi malzemeler de doğal bir yalıtım sağlar. Sibatlar beşik ya da çapraz tonozlarla örtülüdür. Yarı sokak olan bu oluşumlara, evlerin denk gelen noktalarında, bazen küçük boyutlu pencereler açılmıştır ${ }^{5}$.

5 Nurhilal Şimşek, "Mardin Geleneksel Konutlarında Değişimin Mekân Dizimi Yöntemiyle İrdelenmesi” (Yayımlanmamış Yüksek Lisans Tezi), İstanbul Teknik Üniversitesi Fen Bilimleri Enstitüsü, İstanbul, Haziran 2013. 


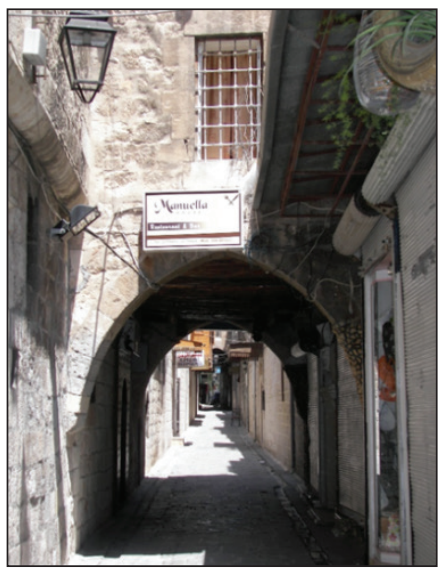

Şekil 6. Halep sokaklarında Sibat (M. Zeyn El Abidin, 2009)

Bu uygulama benzer mimarî dokuya ve iklime sahip olan Mardin, Gaziantep ve Diyarbakır'da görülmektedir. Sibat, genel olarak Güneydoğu Anadolu Bölgesi'nde "kabaltı" olarak bilinen geçişlerdir. Mardin'de ise "Abbara" ismi taşımaktadır. Sokaklarda bu tip geçişlere Gaziantep ve Şanlıurfa'da "kabaltı" denilmektedir. Sibatlar, güneşli ve sıcak yaz günlerinde gölgelik alanlar oluşturmaları ve görsel açıdan tarihi kent sokaklarına derinlik katmaları açısından önemlidir.

\section{Halep Geleneksel Evlerinin Birimleri}

Halep'in geleneksel dokusunda bulunan evler, Mezopotamya mimarisine uygun olarak, dar sokaklar ve çıkmaz sokaklar çevresinde, sokaktan kopuk bir avlu etrafinda oluşmaktadır. Bu mimari, fiziksel çevreye, sosyoekonomik ve kültürel koşullara uygun olarak gelişmiş ekolojik bir olgudur. İslamiyet döneminde de Halep geleneksel evleri, Mezopotamya evlerinin mimarisini devam ettirmiştir6́.

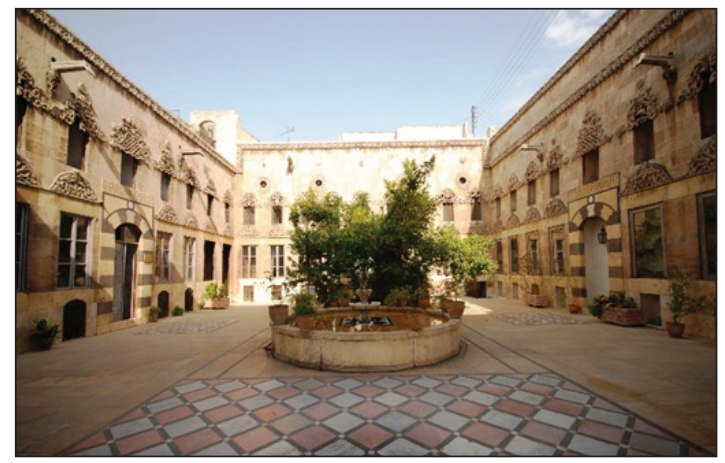

Şekil 7. Açık baş evindeki avlu (M. Zeyn El Abidin, 2008)

6 Mahmud Zeyn El Abidin, Arap ve Türk Evlerinde Tarihsel Gezinti, 1. bs., Riyad, 1989, s.239. 
Osmanlı döneminde geleneksel evler üç ana bölümden oluşmaktadır: Selaml1k bölümü (kabul yeri), harem bölümü (yaşama ve yatma) ve hizmet bölümü (saraylarda veya geniş evlerde hizmetçilere tahsis edilen bölüm). Odalar evin avlusunun etrafinda yer almakta olup tek katta yer alabildikleri gibi iki kata da dağılabilmektedir? .

\subsection{Avlu}

Giriş katındaki biçimlenmeyi belirleyen en önemli öğe olan avlu, Halep evlerinin büyüklüğüne göre boyutlandırılmış olup evin merkezi niteliğindedir. Mekânlar arası bağlantının sağlandığı ortak alandır. Günlük işlerin büyük çoğunluğu burada yapılır. Özellikle yaz aylarında, gündüzleri oturulan ve geceleri yatılan, üstü açık bir oda şeklindedir. Düğün, nişan, taziye gibi eylemlerin gerçekleştirildiği ve özellikle kadınlar için gündelik hayatın geçtiği mekândır. Avlu, evlerin omurgası gibi bir niteliğinde olup eyvanın tamamlayıcısıdır. Halep evlerinde avlu genellikle üstü açık kare veya dikdörtgen şeklindedir. Evin odaları bu avlunun iki tarafında sıralanır.

Avlunun bir diğer özelliği de mutlaka ortasında mermerden yapılmış "bürke" denilen fiskiyeli bir havuz veya bir kuyunun bulunmasıdır. Bu havuzlar suyun sesinin ve serinliğinin hissettirecek şekilde tasarlanmıştır. Havuzlar genelde, kare, dikdörtgen, yuvarlak, altı ve sekiz köşeli olarak yapılmışlardır. Avluda kullanılan ağaçlar genellikle; limon ağacı, kolonya çiçeği, Yasemin çiçeği, Halep Gülü çiçeği olarak sıralanabilir. Her avluda gölge mekân yaratmak amacıyla mutlaka asma bitkisi kullanılmıştır.

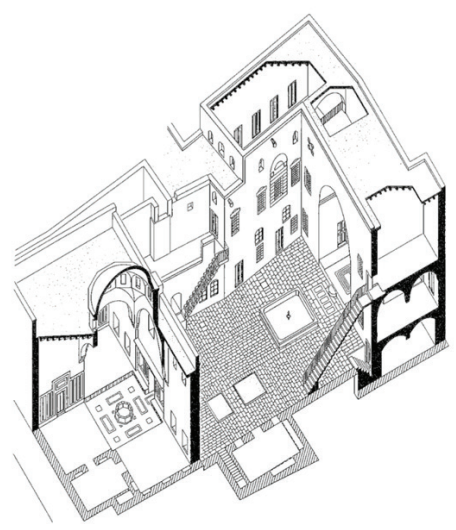

Şekil 8. 17. ve 18. yy.' a ait bir Halep geleneksel evin aksonometrik kesiti (Bianca, Stefano, Urban Form in the Arab World - Past and Present, Zurich, vdf, 2000)

7 Mahmud Zeyn El Abidin, The Courtyard Houses of Syria, Courtyard Housing, Past, Present and Future, Taylor and Francis, 2006. 


\subsection{Odalar}

Kapalı mekânlar arasında, mimarisi nedeniyle tasarımı yönlendiren temel mekân yaşama birimidir. Odalar gündüzleri oturulan, misafir kabul edilen, yemek yenilen; geceleri ise hem oturma hem yatak odası işlevini gören mekânlardır. Konaklardaki ve büyük evlerdeki köşk odaları daha özenli olup, bezemeli ahşap kirişlemeli ya da ahşap kaplamalıdır. Ev tasarımındaki birim tekrarlarının en önemli nedeni ailenin genişlemesiyle yaşama birimine duyulan ihtiyaç olmuştur.

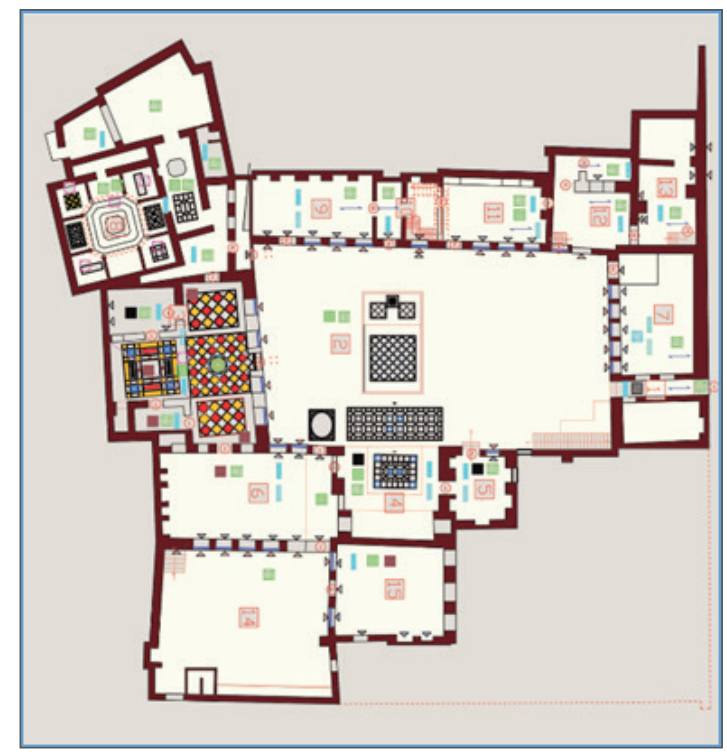

Şekil 9. Halep geleneksel evlerinde avlunun etrafindaki odalar Gazale evinin zemin kat planı

Geleneksel Halep konutunun kapalı mekânları olan odalar, çok amaçlı olarak kurgulanmışlardır. Odalarda; yemek yeme, oturma, yatma, misafir ağırlama ve hatta yıkanma gibi birçok farklı ihtiyaç karşılanır. Odaların iç düzenleri toplumsal özelliklere göre planlanmıştır. Odaların iç duvarları ahşapla kaplı olup (ahşap lambiri), tavanlar yüksek (3 metreye yakın) yukarı kısımlarda da kuş pencereleri bulunmaktadır. Pencereler evin avlusuna bakar, sokağa bakan pencereler genelde cumbalidır.

Evlerin en önemli odaları, kabul odalarıdır. Bu odalar evin en gösterişli ve ferah bölümüne konumlanmış olup genellikle evin zemin katında bulunurlar. Kuzey kanatta yer alan, evin diğer odalarından daha ferah ve bezemeli oda, misafir kabul odası olarak kullanılmaktadır. Bazı odalarda seki altı vardır. Burası ayakkabıların çıkarıldığı bölümdür. Seki altı ile odanın esas oturma bölümü (seki üstü) arasında 20-30 cm'lik kot farkı vardır. 


\subsection{Eyvan}

Genellikle avlu seviyesinde olan ve bir iki basamakla çıkılan eyvan birimi, Halep ev mimarisindeki en önemli öğe sayılır. Eyvanlar yazın güneşten daha az etkilensin diye kuzeye doğru yönlendirilmiştir.

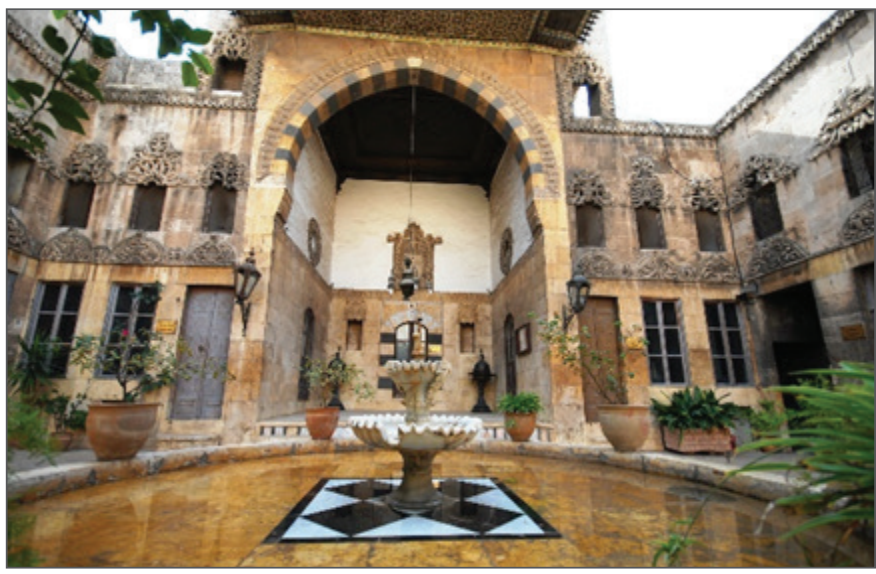

Şekil 10. Açık baş evindeki eyvan (M. Zeyn El Abidin, 2008)

Eyvan ise avludan sonra, özellikle sıcak yaz günlerinde evin en çok kullanılan bölümüdür. Genellikle evin güney kanadında bulunan eyvanlar üç tarafı kapalı ve bir tarafı avluya açılan bir yaz odası şeklindedir

Genelde sıcak iklime sahip yörelere özgü bir mekân olarak karşımıza çıkan eyvan; halkın sosyal yaşamıyla bir bütün oluşturmuştur. Dış etkenlere karşı koruma işlevi gören eyvan, gölgelik görevi üstlenir ayrıca 1şık-gölge karşıtlığı mekânda ince bir ayrım yaratmaktadır.

\subsection{Kiler}

Kiler, bodrum katlarında yer almakta olup, evlerin genellikle depolama amaçı kullanılan mekânlarıdır. Hem yiyeceklerin saklanmasında hem de kışlık yakacak ve erzakların depolanmasında bu kilerler kullanılmıştır. Kilerler, yazın en sıcak günlerinde bile yiyeceklerin uzun süre bozulmadan kalmasını sağlayan bir serinliğe sahiptir.

Kilerlere fazla yüksek olmayan, sade bir kapıdan geçilerek içeriye girilir. Genellikle döşemeleri ve duvarları doğal taş olup, üst örtüsü beşik veya çapraz tonozdur. Bodrum katları, toprağa yarı gömülü olup, bu mekânlar pencerelerle avluya açılmaktadırlar. 


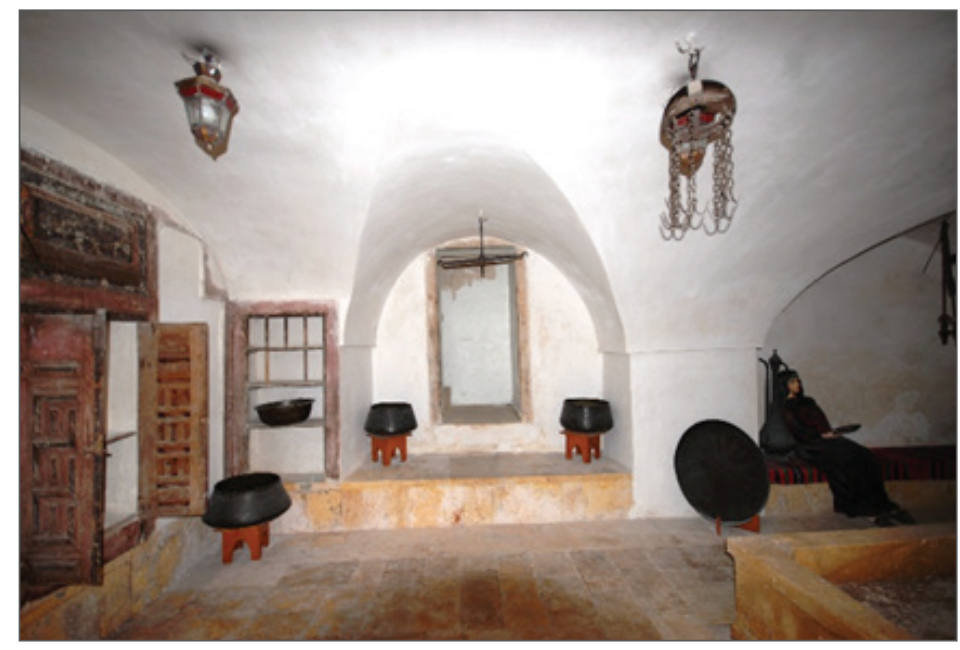

Şekil 11. Açık baş evindeki kiler kısmı (M. Zeyn El Abidin, 2008)

\subsection{Islak Hacimler}

Mutfak, banyo ve tuvalet gibi sslak hacimler, genellikle dış kapıya daha yakındır. Halep’te hamam kültürünün yaygın olması sebebiyle evde banyo vs gibi mekânlara yer verilmemiştir. Çok nadir olarak birkaç evde geleneksel banyo (hamam şeklinde) bulunmaktadır.

Tuvalet birimi genellikle evin ana kapısına daha yakın bir yerde bulunur. Evin diğer birimlerden izole etmek için tuvalete birkaç basamak çıkılarak ulaş1lır. Evin tüm üyelerinin ortak mekânı olduğu için ortak avluya bağlanmışlardır. Bir diğer sebebi de suyun bu mekânlara rahatlıkla ulaşabilmesini sağlamaktır.

\subsection{Damlar}

Konut birimlerinin dışına çıkıldığında evlerin damlarında kültürel bir etki görülmektedir. Damlar, evin çatı kısmını oluşturmaktadır. Zemin kattaki açık mekân gereksinimi avlu tarafından karşılanırken, üst katta avlunun yerini dam almaktadır. Dam, günlük işlerin yapıldığı, mevsimlik yiyeceklerin kurutulduğu, geceleri yatılan ve yaz aylarında yoğun olarak kullanılan açık bir mekândır. 


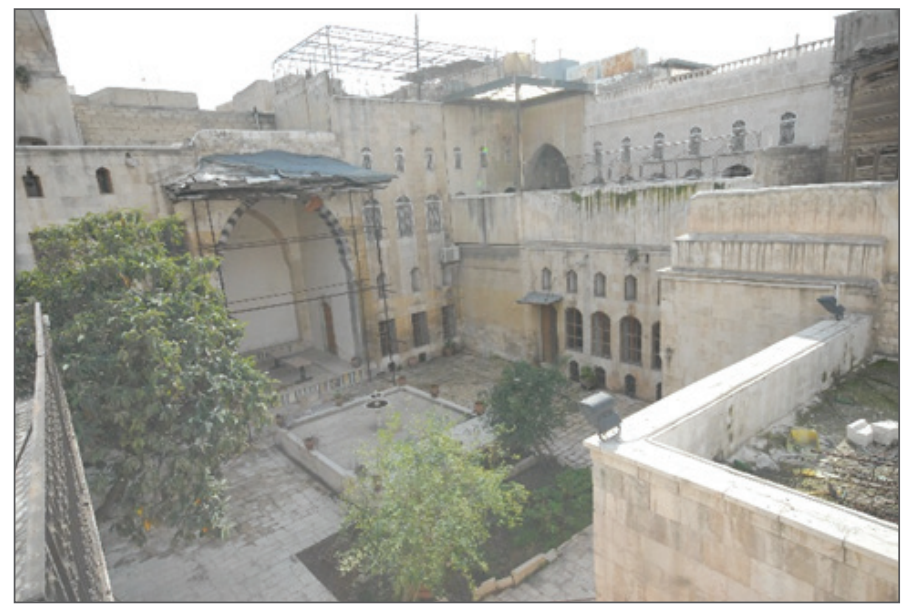

Şekil 12. İbrahim Katırağası evindeki damlar (M. Zeyn El Abidin, 2010)

\section{Yapı Elamanları ve Malzeme Özellikleri}

Halep ev mimarisini oluşturan en önemli etkenlerden bir tanesi yapı malzemesidir. Kentin içinde bulunduğu coğrafi ve jeolojik şartların etkisiyle taş temel yapı malzemelerinden olmuştur. Halep yapılarının genelinde kullanılan taş, geleneksel evlerin de vazgeçilmez öğesi olmuş ve malzeme neredeyse tüm örneklerde aynı şekilde işlenmiştir. Yapılarda aynı taşın benzer şekillerde kullanılması Halep kentinin kendine özgü bir rengi olmasını sağlamıştır. Bu renk, uzaktan tüm kente bakıldığında veyahut içerisinde dolaşıldığında her an fark edilebilmektedir. Kente rengini veren bu malzeme, bölgeye özel açık renkli sarımsı kalker taşıdır.

Yapı malzemesi olarak bölgede en çok bulunan ve en kolay ulaşılabilen Halep taşının kullanımıyla beraber yapım tekniği de önem kazanmıştır. Bölgede taş malzeme kullanımı günümüze kadar devam etmekte ve bu malzemeyi sağlayan faal taş ocakları bulunmaktadır.

Halep ev mimarisinde ayrıca tuğla ve kerpiç gibi toprak kökenli malzemeler de kullanılır. Bunlar daha çok tonoz, kubbe ve kemerlerde işlenmiştir. Kapı, pencere, duvar kaplamaları ve tavanlarda ahşap; merdiven, pencere ve balkon korkuluklarında demir ve benzeri madenî malzemeler kullanılır. 

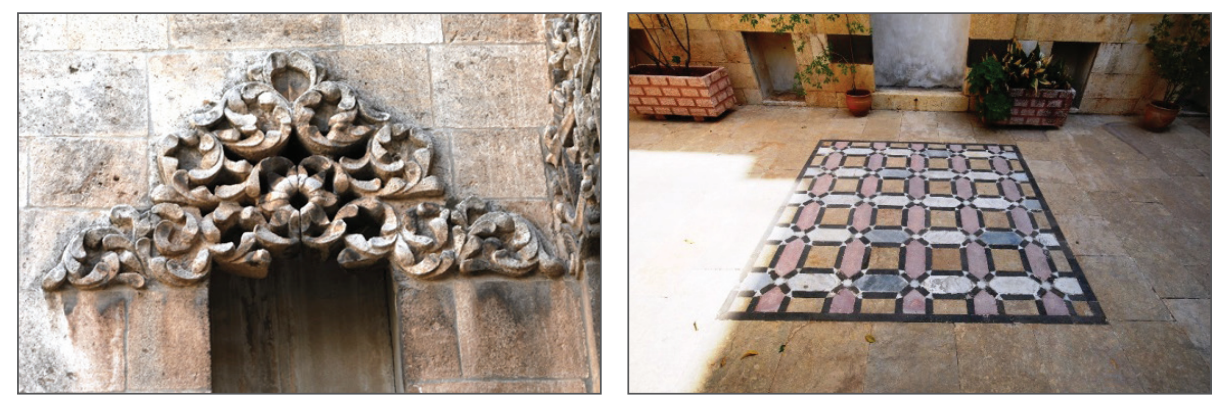

Şekil 13. Halep evlerinde kullanılan taş (M. Zeyn El Abidin, 2008)

\section{Sonuç}

En az beş bin yıllık bir geçmişe sahip olduğu tahmin edilen Halep'in, geleneksel evleri de yüzyılların verdiği tecrübe sonucunda gelişerek, şehrin tarihi kimliğine ve iklim şartlarına en uygun duruma gelmiştir.

Evler, avlulu olarak tasarlanmıştır. Bütün odalar avluya dönük olarak inşa edilmiştir. Evlerde haremlik-selamlık bölümlerine yer verilmiştir. Evler genel olarak iki katlıdır. Üst kattaki oda sayısı daha azdır. Bütün odaların duvarlarında alt pencerelere ve tepe pencerelerine yer verilmiştir. İklim nedeniyle odaların yükseklikleri ve buna bağlı olarak tavanların yükseklikleri fazla tutulmuştur. Odalarda sıkça rastladığımız tepe pencereleri içerdeki sıcak havanın dışarıya çıkmasını sağlamaktadır.

Ev mimarisini etkileyen diğer önemli bir unsur da aile yaşantısının gizli tutulması esasını içermesidir. Böylece evin mahremiyeti yüksek duvarların arkasına gizlenmiş, dışarıya açılmamıştır. Bu durum yalnızca, dışarıya kapanma şeklinde olmamıştır.

Evlerde yapı malzemesi olarak taş kullanılmıştır. Taş, Halep ve çevresinde kolaylıkla bulunabilen bir malzemedir. Bu yüzden Halep yapılarında çokça kullanılmıştır. Evlerde özgün yapım sistemi yığma, kullanılan ana yapı malzemesi ise taştır. Moloz taş duvarlar kesme taşla kaplanmıştır.

Sonuç olarak, Halep geleneksel evlerinin plan tipolojisi olarak avluya sahip olup, avlunun etrafında odalar yer almaktadır. Karşımıza çıkan bu plan tipinin Mezopotamya döneminin anılarını günümüze kadar ulaştırdığı söylenebilir. 


\section{Kaynakça}

Abdurrahman, Hamide, Muhafazat Halep, Şam, Menşurat Vüzaretü's-Sakafa, 2006.

el-Rifai, Mahmut Faysal, Halep Beyne't-Tarih ve'l-Hendese, Camiat Halep, Ma'had el-Turas el-'İlmi el-'Arabi, 1417 H./1996 M.

Raymound, Andre, el- 'Avasim el- 'Arabiyye ve 'Umraniha fi'l-Fetretü'l-Osmaniye, çev. Kasım Tuveyr, Şam, Darü'l-Mecd, 1986.

Şimşek, Nurhilal, "Mardin Geleneksel Konutlarında Değişimin Mekân Dizimi Yöntemiyle İrdelenmesi” (Yayımlanmamış Yüksek Lisans Tezi), İstanbul Teknik Üniversitesi Fen Bilimleri Enstitüsü, İstanbul, Haziran 2013.

Zeyn El Abidin, Mahmud, Arap ve Türk Evlerinde Tarihsel Gezinti, 1. bs., Riyad, 1989.

, The Courtyard Houses of Syria, Courtyard Housing, Past, Present and Future, Taylor and Francis, 2006. 